\title{
Makna Kata Anuq dalam Bahasa Sasak di SMP Negeri 2 Batukliang Utara
}

\author{
Hollysa Andini, Mahyuni, dan Nuriadi \\ Program Pascasarjana, Universitas Mataram \\ icokk22jinyesever@gmail.com
}

\begin{abstract}
This research is aimed at describing the meaning of the word "anuq" which is commonly spoken by Sasak people in SMP Negeri 2 Batukliang Utara using semantics theory. The source of data were the conversations among teachers and administrators of SMP Negeri 2 Batukliang Utara. The data were collected by applying listening, speaking, and introspection method. The result of the research showed that the word "anuq"has many meanings based on the context or topics of the communication. Sasak people in SMP Negeri 2 Batukliang Utara basically used "anuq" when the speaker forgot or lost the word to be spoken.

Keywords : Anuq; context; semantics; Sasak language.

\section{Intisari}

Penelitian ini bertujuan untuk mendeskripsikan makna kata anuq yang biasa digunakan oleh masyarakat tutur bahasa Sasak di SMP Negeri 2 Batukliang Utara dengan menggunakan teori semantik. Sumber data penelitian adalah percakapan beberapa pendidik (guru) dan pegawai tata usaha di SMP Negeri 2 Batukliang Utara. Adapun pengumpulan data dilakukan dengan mengaplikasikan metode simak, metode cakap, dan metode instrospeksi. Hasil penelitian menunjukkan bahwa kata anuq itu sendiri memiliki makna yang begitu beragam. Makna tersebut disimpulkan berdasarkan konteks atau topik pembicaraan dalam berkomunikasi. Kebiasaan masyarakat tutur Sasak di sekolah tersebut menggunakan kata anuq pada dasarnya digunakan sebagai pengisi kata ketika penutur lupa atau kehilangan kosakata yang ingin diucapkan. Jadi, dapat disimpulkan bahwa kata anuq memiliki beragam makna berdasarkan konteks pembicaaran pada saat kata itu digunakan. Kata kunci: Anuq; konteks; semantik; bahasa Sasak.
\end{abstract}

\section{Pendahuluan}

Berkomunikasi dan berinteraksi baik di sebuah kelompok masyarakat atau di luar kelompok tersebut haruslah memiliki media atau alat komunikasi agar tujuan tuturan tercapai, saling memahami maksud sehingga tidak terjadi ketimpangan antar penutur karena prinsipnya ketika terjadi komunikasi antara dua orang atau lebih terutama komunikasi lisan maka haruslah kedua belah pihak memahami maksud lawan bicara sehingga ide atau konteks yang dibahas dapat terjalin dengan baik. Media atau alat yang digunakan dalam berkmunikasi tersebut adalah bahasa baik itu bahasa pertama maupun bahasa kedua dan bahasa asing. 
Tuturan-tuturan yang dikonkretkan dalam berkomunikasi menjadikan keberagaman bahasa yang ada di dalam masyarakat tutur. Dalam setiap tuturan pemilihan kata (diksi) menjadi hal penting untuk diperhatikan karena dengan diksi yang baik maka akan terjalin komunikasi yang baik pula. Salah satu kata yang sering digunakan adalah kata anuq, penggunaan kata ini lebih banyak terdengar pada penutur Sasak.

Dilihat dari segi fungsi, kata anuq semata-mata hanya terpakai pada saat pembicaranya merasa terpojok (get stuck) karena sedikit lupa atau kehilangan informasi, ide dan gagasan tentang apa yang harus diucapkan atas sesuatu yang sedang dibahasnya. Tanpa dipikirkan terlebih dahulu, kata anuq itu muncul begitu saja dalam sebuah pembicaraan karena memang begitu mudahnya diucapkan. Artinya, diucapakan secara otomatis dan spontan. Dalam ilmu linguistik kata anuq tergolong ke dalam pronomina penunjuk umum.

Umumnya, dalam sebuah kegiatan berkomunikasi lisan antara dua orang atau lebih seringkali terdengar pengggunaan kata anuq seolah-olah penutur bahasa Sasak memilih untuk lebih banyak menggunakan kata anuq sebagai pengisi kata yang seharusnya ingin disampaikan. Pengguna (penutur) kata inipun tidak terbatas. Artinya, penutur yang "terbiasa" menggunakannya tidak hanya kalangan orang dewasa tetapi juga anak-anak, tidak hanya masyarakat dengan tingkat pendidikan rendah tetapi juga masyarakat yang pendidikannya tinggi, ataupun dengan derajat yang bagus di dalam masyarakat. Disebabkan intensitas penggunaan yang begitu sering dan bahkan karena intensitas penggunaan tersebut lebih banyak membuat lawan tutur ketika berkomunikasi harus berpikir ekstra agar memahami maksud dari kata anuq tersebut.

Jadi, kata dan kalimat apapun yang dilupakan dalam sebuah pembicaraan dapat digantikan dengan segera mengucapkan kata anuq. Hal tersebut menyebabkan kata Anuq memiliki makna yang berbeda-beda (variatif) dalam sebuah kegiatan berkomunikasi. Makna kata anuq itu tergantung pada kata dan kalimat, ide atau gagasan yang dilupakan oleh sang pembicara sebagai ungkapan penyambung untuk sementara waktu (jeda) di saat pembicaraan itu berlangsung agar pembicaraannya tidak terputuskan.

Sejauh ini penelitian terdahulu yang membahas kata anuq belum ditemukan oleh peneliti terlebih dalam bahasa Sasak namun, salah satu penelitian yang membahas makna dan data yang diperoleh berupa bahasa Sasak adalah penelitian yang berjudul Bentuk, Fungsi, dan Makna Idiom Bahasa Sasak sebagai Suplemen dalam Pembelajaran Muatan 
Lokal Di SMP (Studi di Desa Bunut Baok) yang merupakan hasil dari Moh. Iwan Fatiri (2017). Objek penelitian ini adalah idiom bahasa Sasak yang mana idiom tersebut dimaknai berdasarkan makna positif, negatif dan komparasi keduanya. Penelitian ini mendapatkan 60 idiom dalam bahasa Sasak yang kemudian dikelompokkan berdasarkan keeratan nsur, sumber, dan fungsinya yang kemudian ditentukan makna-maknanya.

Untuk pemerolehan simpulan makna pada kata anuq ini maka peneliti menggunakan teori semantik. Secara umum, kajian semantik membahas tentang makna pada sebuah kata sesuai dengan penjelasan Verhaar (2012) yang menyatakan bahwa semantik adalah cabang linguistik yang menelit arti atau makna. Chaer (2007) menjelaskan pula bahwa studi semantik lazim diartikan sebagai bidang dalam linguistik yang meneliti atau membicarakan, atau mengambil makna bahasa sebagai objek kajiannya. Penyebutan "makna bahasa" dikedepankan karena dalam kebudayaan yang mempunyai makna bukan hanya bahasa, melainkan lambang-lambang, simbol, dan tanda-tanda lainnya. Untuk itu haruslah dibedakan pengguaan makna apakah makna bahasa atau makna yang lain karena walaupuan keduanya membahas tentang makna tetapi kajian atau teori yang digunakan akan berbeda. Makna bahasa (kata) menggunakan kajian semantik sedangkan makna tanda, simbol, dan lain-lainnya menggunakan kajian semiotik.

Di dalam pemaknaan terdapat beberapa jenis makna yang diketahui. Chaer (2007) menjelaskan lima jenis makna, yaitu makna leksikal, makna gramatikal, maka kontekstual, makna idiomatikal, dan makna konotasi.

Jenis makna yang ketiga dan yang menjadi fokus utama penelitian ini adalah makna kontekstual. Dalam berkomunikasi sehari-hari penggunaan makna leksikal dan makna gramatikal sangat jarang digunakan, masyarakat lebih banyak menggunakan makna kontekstual ini. Hal ini dikarekan sebuah kata akan terlihat jelas maknanya apabla berada di dalam konteks yang jelas pula sehingga lawan tutur seorang peutur akan lebih cepat memahami maksud dari apa yang dibicarakan. Chaer pun menjelaskan konteks yang dimaksud, terdapat beberapa konteks yang dapat merubah makna kata, di antaranya konteks linguistik, konteks situasi (tenpat dan waktu) konteks bidang kegiatan atau keilmuan, bidang sosial dan budaya, dan lain-lain.

Konteks linguistik artinya kedudukan kata itu di dalam satuan linguistik, bisa dalam satuan frase, satuan kalimat, maupun satuan pragraf. Konteks situasi biasanya berkenaan dengan waktu dan tempat satuan bahasa yang digunakan. Konteks bidang 
kegiatan atau keilmuan adalah masalah penggunaan kata dalam suatu bidang kegiatan tertent atau suatu keilmuan tertentu, dan dalam konteks budaya dan kehidupan sosial terdapat sejumlah kata yang digunakan bukan dalam makna leksikalnya, tetapi dalam makna asosiasi yaitu pengertian lain yang berkaitan dengan makna leksikalnya dan makna ini tidak terdapat di dalam kamus melainkan dipahami oleh bahasawan dari pengguna bahasa tersebut.

Konteks verbal menjelaskan bahwa istilah "konteks" tidak hanya terbatas pada kata yang mendahului dan mengikuti sebuah kata, melainkan dapat meliputi keseluruhan wacana di mana kata tersebut berada. Artinya, sebuah kata dapat ditentukan dan dimaknai pengertiannya setelah membaca dan memahami keseluruhan wacana tempat kata tersebut diaplikasikan. Selain adanya konteks verbal, dalam mencari makna kata juga dipengaruhi oleh konteks situasi. Konteks ini diperkenalkan ke dalam linguistik oleh seorang antropolog Broinslaw Malinowski, di dalam buku Semantik karya Stephen Ullman yang diadaptasi oleh Sumarsono (2014: 59-60) memaparkan bahwa konteks situasi tidak hanya berarti situasi yang sebenarnya tempat ujaran terjadi, tetapi juga menyangkut keseluruhan latar belakang budaya di mana peristiwa tutur itu muncul.

Secara umum terdapat dua jenis pengaruh konteks terhadap makna, yaitu yang berpengaruh terhadap apa saja dan yang lebih besar berpengaruhnya terhadap beberapa kata daripada kata yang lain. Maksutnya, walaupun sebuah kata sudah tepat dan pasti maknanya, memiliki makna inheren, tetapi akan menurunkan makna dari konteks dalam ujaran-ujaran yang lebih spesifik. Hal ini berlaku bagi nama diri. Di samping itu, konteks juga memegang peranan penting dalam memastikan makna kata yang samar atau kabur apabila sebuah kata berdiri sendiri. Jenis kekaburan atau keambiguan makna kata atau penentuan makna kata yang didasarkan oleh konteks terjadi pada kata yang mempunyai berbagai kemungkinan untuk masuk ke berbagai jenis kata. Peranan konteks ini banyak dimanfaatkan dalam hal homonim yang mana satu kata dengan tulisan dan ejaan yang sama namun berbeda makna. Kata yang berhomonim akan diketahui maknanya melalui peran konteks.

Dalam penelitian ini yang akan dicari makna kata adalah kata anuq yang mana diprediksi memiliki variasi makna yang sangat banyak tergantung pada konteks kata ini berada. Yang diketahui selama ini kata anuq memiliki fungsi hanya sebagai pengisi kata 
yang mana dilupakan oleh penutur ketika sedang melakukan komnuikasi secara lisan. Namun, akan dianalisis lebih teliti melalui penelitian ini.

Samsuri (2008) kata "makna" diartikan seperti ini: (1) arti; (2) maksud pembicara atau penulis; pengertian yang diberikan kepada suatu bentuk kebahasaan. Menurut Ullman (1972) terdapat tiga hal yang berkaitan dengan makna, yaitu name, sense, dan thing. Soal makna terdapat dalam sense, dan terdapat hubungan timbal balik antara nama dengan pengertian sense. Ullman (diadaptasi oleh Sumarsono, 2014:68) menjelaskan name (nama) adalah bentuk fonetis sesuatu kata, bunyi-bunyi yang membentuk kata, termasuk unsurunsur akustik lain seperti aksen. Makna adalah informasi yang dibawa oleh nama untuk disampaikan kepada pendengar, sedangkan benda (thing atau referen) merupakan unsur atau peristiwa nonbahasa yang kita bicarakan.

Umumnya, terdapat dua pendekatan dalam membahas makna. Dua pendekatan tersebut adalah pendekatan analitik atau referensial dan pendekatan operasional. Pateda (2001: 86) menjelaskan bahwa pendekatan analitik ingin mencari makna dengan cara menguraikan atas segmen-segmen utama, sedangkan pendekatan operasional ingin mempelajari kata dalam penggunaannya.

Pateda menjelaskan perbedaan kedua pendekatan tersebut dengan sebuah contoh kata istri. Dilihat dari pendekatan analitik, kata istri diuraikan menjadi: perempuan; telah bersuami; kemungkinan telah beranak; manusia; berambut panjang; berfungsi sebagai pendamping suaami dll. Akan tetapi, dilihat dari pendekatan operasional, kata istri akan terlihat dari kemungkinan-kemungkinan pemunculannya dalam kalimat, misalkan: Si Dula mempunyai istri, banyak istri yang bekerja di kantor, dll. Berdasarkan contoh di atas dapat disimpulkan bahwa pendekatan analitik pemaknaan kata berdasarkan makna kamus dan sudah inheren di dalam kata tersebut. Berbeda halnya dengan pendekatan operasional yang menyimpulkan makna sebuah kata berdasarkan pengaplikasian kata tersebut ke dalam sebuah kalimat. Artinya, pendekatan operasional lebih menekankan bagaimana kata tersebut dioperasikan di dalam tindak sehari-hari.

Sejalan dengan penjelasan Ullman (diadaptasi oleh Sumarsono, 2014: 66-67) terdapat dua aliran linguistik, yaitu pendekatan analitik atau referensial dan pendekatan operasional. Pendekatan analitik yang terkenal adalah model segitiga dasar yang dikemukakan oleh Ogden dan Richards yang mana esensi model ini, yaitu membedakan 
tiga komponen makna. Ketiga komponen tersebut adalah lambang (kata), pikiran atau refernsi, dan referen atau acuan.

Selain kedua pendekatan di atas, pendekatan untuk makna dapat juga dilihat dari hubungan fungsi yang berbeda di dalam bahasa. Pateda (2001: 87-88) menjelaskan dua pendekatan tersebut, yaitu pendekatan ekstensional dan pendekatan intensional. Pendekatan ekstensional ialah pendekatan yang memusatkan perhatian pada penggunaan kata di dalam konteks, sedangkan pendekatan intensional ialah pendekatan yang memusatkan perhatian pada struktur-struktur konseptual yang berhubungan dengan unitunit utama.

\section{Metode Penelitian}

Penelitian kualitatif ini menguraikan makna kata anuq yang dikaitkan dengan konteks dalam penggunaannya. Data penelitian berupa data lisan hasil percakapan narasumber yang kemudian ditranskrip kemudian dideskripsikan makna kata anuq yang ada di dalam percakapan tersebut. Adapun narasumber yang digunakan adalah 10 orang di antaranya 5 orang guru dan 5 orang pegawai tata usaha di SMPN 2 Batukliang Utara.

Data dikumpulkan menggunakan metode simak dan catat dengan teknik dasar yaitu teknik simak bebas libat cakap (SBLC) dan simak libat cakap (SLC) (Mahsun, 2017). Metode instropeksi juga menjadi metode tambahan dalam pengumpulan data. Adapun analisis data menggunakan metode deskriptif kualitatif dengan memperhatikan konteks yang berlangsung dalam percakapan kemudian dari konteks tersebut akan mendapatkan makna kata anuq sesuai kebutuhan.

\section{Hasil dan Pembahasan}

Berdasarkan pemaparan di atas, yang akan menjadi fokus utama dalam penelitian ini adalah kemunculan kata anuq dalam komunikasi lisan yang terjadi baik antara guru dengan guru, guru dengan pegawai tata usaha, dan antarpegawai tata usaha kemudia keunculan kata tersebut akan dikaitkan dengan konteks yang terjalin sehingga akan mendapatkan makna dari kata tersebut. Keseluruhan data yang diperoleh akan di transkrip kemudian dipilih percakapan yang akan dianalisis.

Di bawah ini akan dipaparkan transkrip data beserta penjabaran makna kata anuq yang diperoleh berdasarkan konteks pembicaraan yang terjalin di dalam komunikasi beberapa guru dan pegawai tata usaha di SMP Negeri 2 Batukliang Utara

Data 1 
Bu Ratna: kan baruk ite nyugulan pade 10rb endih Bu Nia?

(Bu Ratna: tadi kita iuran masing-masing 10rb, betul Bu Nia?)

Bu Nia: tumbenn tame tie Pak Hakam ye surun endekn taon.

(Bu Nia: tumben Pak Hakam masuk sekolah itu Bu makanya dia tidak tahu)

Bu Ratna: angkak baruk kan Bu Hesfi anuq-anuq tame lek kelas.

(Bu Ratna: iya, makanya barusan Bu Hesfi anuq-anuq masuk ke dalam kelas)

Komunikasi di atas terjadi di ruang tata usaha yang melibatkan Bu Ratna dan Bu Nia serta beberapa bapak guru yang berada di tempat yang sama. Akan tetapi, penggunaan kata anuq dalam komunikasi terjadi ketika pecakapan yang berlangsung antara Bu Nia dan Bu Ratna. Konteks pembahasan yang terlihat dari hasil transkrip di atas adalah membahas tentang pendanaan konsumsi guru dan TU yang akan membuat soto. Bu Ratna bertanya kepada salah satu bapak guru yang ternyata tidak mengetahui rencana pendanaan tersebut sehingga ia bercerita bahwa salah satu ibu guru mendatangi setiap kelas untuk meminta uang iuran. Penggunaan kata anuq dalam percakapan di atas bermakna "meminta" atau "menagih" uang iuran pada masing-masing guru. Disimpulkan seperti itu karena "meminta atau menagih" sesuai dengan konteks pembicaraan. Hal tersebut diperkuat oleh gestur tubuh dari penutur (Bu Ratna) yang mana beliau menengadahkan tangan seperti orang meminta sehingga kata anuq dalam konteks percakapan di atas adalah "meminta atau menagih."

Data 2

Bu Nur: kopian bae tie anukn muk kerisakn embe hak anuk.

(Bu Nur: dikopikan saja anuq itu kemudian perbaiki mana yang anuq)

Pak H. Humaidi: mun gentik arann doang ni sik Pak Aci. Alamatn Irham ni jak.

(Pak H. Humaidi: diganti nama saja sama Pak Aci ini, alamtnya itu alamat Pak Irham)

Konteks komunikasi di atas tentang kesalahan data pada penerbitan SK honorer oleh kepala sekolah. SK yang salah adalah SK milik Ibu Hollysa yang mana tanggal lahir dan alamat yang tertera pada SK tersebut tidak sesuai dengan KTP kemudian Bu Nur yang berada di ruangan yang sama berkomentar dengan memberi saran. Bu Nur dalam memberikan saran menggunakan kata anuq sebanyak dua kali dan dalam konteks percakapan di atas anuq yang pertama bermakna "SK atau surat keterangan" dan anuq yang kedua bermakna "salah". Penggunaan anuq yang pertam dimaknai dengan "SK atau surat keterangan" karena benda yang salah pada konteks percakapan di atas adalah SK milik Bu Hollysa dan pada saat itu beberapa guru honor lainnya diberikan SK masingmasing. Anuq yang kedua dimaknai "salah” karena Bu Nur berkata “... muk kerisak embe 
hak anuk." pernyataan tersebut merupakan saran agar memperbaiki data yang salah sehingga anuk yang kedua dimaknai dengan "salah".

Data 3

Pak Muhnam: pire anukn ni setiap grup Pak Ir?

(Pak Muhnam: berapa anuqn setiap grup ini Pak Ir)

Pak Roby: 10 orang satu grup pak.

(Pak Roby: 10 orang dalam satu grup, Pak)

Pak Muhnam: hak nine endah?

(Pak Muhnam: yang perempuan juga?)

Pak Irham: endk semaik waktun lamun hak wanina endah pak.

(Pak Irham: tidak cukup waktunya kalau wanita juga main Pak)

Komunikasi di atas berlangsung di depan ruang tata usaha ketika Pak Muhnam selaku wakasek kesiswaan bertanya kepada dua orang guru olahraga yang sedang berdiri di koridor ruang tata usaha. Saat itu di lapangan terlihat siswa-siswa sedang bermain bola. Kemudia Pak Muhnam bertanya perihal classmeeting sepak bola yang akan dilaksanakan setelah ujian tengah semester. Pada percakapan tersebut Pak Muhanm menggunakan kata апиq ketika bertanya dan berdasarkan konteks pembicaraannya kata tersebut bermakna 'anggota" karena pertanyaan Pak Muhnam dijawab oleh Pak Roby dengan jumlah orang dalam satu grup sehingga jika dikaitkan dengan konteks pembahasan dalam perckapan tersebut maka dapat disimpulkan bahwa kata anuq dalam konteks tersebut bermakna "anggota". Diperkuat dengan Pak Muhnam yang berbincang dengan guru olahraga dan tugas beliau yang harus mengurus acara classmeeting tersebut.

Data 4

Pak Saleh: paling murik sogol arann.

(Pak Saleh: saya keluar kelas paling akhir)

Bu Widi: wahm tandatangan tie?

(Bu Widi: sudah tandatangan itu Pak?)

Pak Saleh: memang 09.30 waktun anuk ni Wan?

(Pak Saleh: memang pukul 09.30 waktunya anuq ini Wan?)

Pak Mardi: ye wah pak. Ye lek jadwaln.

(Pak Mardi: ya Pak. Di jadwalnya begitu)

Penggunaan kata anuq terjadi pada percakapan di atas antara Pak Saleh dan Pak Mardi. Keduanya berbincang di ruang tata usaha selagi Pak Saleh mengumpulkan lembar jawaban seusai beliau mengawas. Saat itu merupakan jadwal Pak Saleh untuk megawas di salah satu ruang kelas. Dari sekian kelas yang tersedia hanya kelas tempat Pak Saleh yang paling 
terlambat selesai dan keluar kelas. Pada akhir waktu yang dialokasikan untuk ujian mata pelajaran pertama berakhir akhirnya Pak Saleh keluar ruangan dan melihat siswa-siswi berhamburan di lapangan dan beliau tersadar bahwa waktu untuk mata pelajaran pertama telah usai. Akhirnya, sesampainya beliau di ruang tata usaha kemudian bertanya kepada Pak Mardi tentang kapan waktu istirahat yang sebenarnya. Dapat dibaca dari pertanyaan Pak Saleh pada data 4 di atas bahwa kata anuq muncul. Berdasarkan konteks pembicaraannya kata anuq dapat disimpulkan bermakna "keluar atau istirahat". Dimaknai seperti itu karena seusai jadwal yang tertera, yaitu pukul 09.30 Wita adalah waktu siswasiswi untuk istirahat ujian pertama dan atas dasar keheranan Pak Saleh karena banyak siswa-siswi yang bermain di lapangan serta ruang kelas sudah terlihat kosong ketika beliau keluar dari ruag mengawas.

Data 5

Pak Irfan: arak pulsa Pak Mardi?

(Pak Irfan: ada saldo pulsanya Pak Mardi?)

Pak Mardi: arakn.

(Pak Mardi: ada)

Pak Irfan: yakn bih masa aktifn pulsa ni.

(Pak Irfan: akan habis masa aktifnya pulsa saya ini)

Pak Mukti: aku bae yakn pelot anukk ni. Maeh aku ngisik endah menu, kartu Ask ni yakn pelot.

(Pak Mukti: saya juga akan mati anuqk ini. Saya juga mau isi pulsa kalau begitu ke kartu As saya)

Percakapan di atas berlangsung antara salah seorang pegawai tata usaha dengan dua orang guru yang ingin membeli pulsa. Diawali oleh Pak Irfan yang bertanya kepada Pak Mardi tentang saldo pulsa yang kemudian dijawab ada oleh Pak Mardi. Pak Mukti yang pada saat bersamaan berada di tempat yang sama dan mengalami hal yang sama, yaitu kehabisan pulsa maka meminta untuk Pak Mardi mengisikannya pulsa juga. Dari permintaan Pak Mukti inilah kemudian muncul kata anuq yang mana digunakan oleh Pak Mukti. Berdasarkan konteks pembicaraan yang terjadi dapat disimpulkan bahwa kata anuq tersebut bermakna "pulsa". "Pulsa" yang dimaksud adalah pulsa dari kartu yang digunakan oleh Pak Mukti. Sejalan dengan konteks pembicaraan yang berlangsung antara penutur dan petutur.

Data 6

Bu Wen: arak hak sekat-sekat bebayah lamun berutangan Bu Yem? 
(Bu Wen: kalau ada yang berhutang, pas bayar ada yang lama Bu?)

Bu Yem: arakn hak anuk-anukan memang. Lek Praya taokn tetukak 2,8 juta. Jangke nani endkamn tulak kepengk.

(Bu Yem: ada yang anuq-anuqan. Di Praya sekitar 2,8 juta masih sampai sekarang belum dikembalikan uang saya)

Berdasarkan konteks pembicaraan di atas, kata anuq dapat dimaknai dengan "nakal". Makna ini bukan berarti "nakal" layaknya anak kecil yang tidak bisa diatur melainkan "nakal" yang dimaksud adalah perilaku dari si penghutang yang lama membayar bahkan tidak mau membayar sampai batas waktu yang ditentukan. Hal tersebut diperkuat dengan pernyataan dari petutur yang merasa dirugikan oleh penghutang.

\section{Data 7}

Pak Mulki: Nur, maeh kembek singgak steples. Yak steples bukun kanak ni. Pak Mulki: Nur, pinjam steples. Saya mau stepleskan siswa bukunya ini.

Bu Nurlaili: endk bedoe aku. (sambil berdiri) Bu anuq arak bedoem anuq nike?

Bu Nurlaili: saya tidak punya steples pak. (sambil berdiri) Bu anuq punya steples?

Bu Nia: endk arak (sambil menggeleng)

Bu Nia: tidak ada.

Latar percakapan di atas terjadi di ruang tata usaha antara beberapa pegawai tata usaha dan guru. Pak Mulki yang memang memiliki tugas memperbaiki buku siswa yang rusak sedang kebingungan mencari steples di ruang tata usaha kemudian bertanya pada $\mathrm{Bu}$ Nurlaili selaku pegawai di sana juga yang mungkin saja pernah meminjam atau melihat steples yang dicari. Namun, Bu Nurlaili tidak tahu steples it di mana. Akhirya, Bu Nurlaili berdiri sambil memandang salah seorang guru di ruangan tersebut. Berdasarkan percakapan tersebut kata anuq muncul sebanyak dua kali oleh seorang petutur, yaitu Bu Nurlaili. Anuq yang pertama dapat disimpulkan bermakna "Bu Nia". Hal tersebut dikarenakan selain memang secara langsung $\mathrm{Bu}$ Nia yang menjawab secara otomatis maksudnyaadalah $\mathrm{Bu}$ Nia juga karena di dalam ruangan tersebut hanya terdiri dari beberapa guru dan salah satunya adalah Bu Nia. Selain itu juga, Bu Nurlaili ketika bertanya, dia mengahdap ke arah $\mathrm{Bu}$ Nia sedangkan anuq yang kedua dimaknai dengan "steples". Ditarik keseimpulan seperti itu karena konteks atau topik yang dibahas dalam percakapan tersebut adalah tentang steples yang hilang diperkuat dengan $\mathrm{Bu}$ Nurlaili bertanya pada Bu Nia sambil menggerakkan tangan seperti sedang menyeteples. 


\section{Simpulan}

Berdasarkan uraian di atas dapat disimpulkan bahwa kata anuq pada dasarnya difungsikan sebagai pengisi kata yang dilupakan oleh penutur, tetapi setelah dilakukan penelitian, kata anuq memiliki makna yang sangat beragam. Makna-makna tersebut didapatkan berdasarkan konteks pembicaraan ketika kata anuq ini muncul dan digunakan oleh masyarakat tutur bahasa Sasak. Kata ini memang termasuk kata yang spontan dan sering digunakan ketika berkomunikasi bahkan masyarakat seolah-olah dengan nsengaja menggunakan kata anuq agar memudahkannya dalam menyampaikan maksud pembicaraan. Namun, hal tersebut membuat lawan tuturnya harus bekerja keras untuk berpikir apa makna kata anuq yang dimaksud oleh petutur. Pemahaman konteks pembicaraan ketika berkomunikasi sangatlah penting untuk dilakukan.

\section{Daftar Pustaka}

Arikunto, Suharsimi. 2007. Menejemen Penelitian. Jakarta: PT Rineka Cipta.

Chaer, Abdul . 2012. Linguistik Umum. Jakarta: PT Rineka Cipta.

. 2007. Leksikologi \&Leksikografi Indonesia. Jakarta: PT Rineka Cipta.

Fatiri, Moh. Iwan. 2017. Bentuk, Fungsi dan Makna Idiom Bahasa Sasak Sebagai Suplemen Dalam Pembelajaran Muatan Lokal Di SMP (Studi Di Desa Bunut Baok). Mataram: Universitas Mataram Press.

Mahsun. 2017. Metode Penelitian Bahasa: Tahapan, Strategi, Metode, dan Tekninya. Depok: PT Rajagrafindo Persada.

Samsuri, Hamzah. 2008. Kamus Lengkap Bahasa Indonesia Modern. Surabaya: Greisinda Press Surabaya.

Sugiyono. 2007. Memahami Penelitian Kualitatif. Bandung: CV Alfbeta.

Verhaar, J. W. M. 2012. Asas-asas Linguistik Umum. Yogyakarta: Gadjah Mada University Press. 